\title{
RESEARCH
}

Open Access

\section{Characterising cellular and molecular features of human peripheral nerve degeneration}

\author{
Matthew B. Wilcox ${ }^{1,2,3}$, Simão G Laranjeira ${ }^{3,4}$, Tuula M. Eriksson ${ }^{5}$, Kristjan R. Jessen ${ }^{3,6}$, Rhona Mirsky ${ }^{3,6}$, \\ Tom J. Quick ${ }^{1,3}$ and James B. Phillips ${ }^{2,3^{*}}$
}

\begin{abstract}
Nerve regeneration is a key biological process in those recovering from neural trauma. From animal models it is known that the regenerative capacity of the peripheral nervous system (PNS) relies heavily on the remarkable ability of Schwann cells to undergo a phenotypic shift from a myelinating phenotype to one that is supportive of neural regeneration. In rodents, a great deal is known about the molecules that control this process, such as the transcription factors c-Jun and early growth response protein 2 (EGR2/KROX20), or mark the cells and cellular changes involved, including SOX10 and P75 neurotrophin receptor (p75NTR). However, ethical and practical challenges associated with studying human nerve injury have meant that little is known about human nerve regeneration.

The present study addresses this issue, analysing 34 denervated and five healthy nerve samples from 27 patients retrieved during reconstructive nerve procedures. Using immunohistochemistry and Real-Time quantitative Polymerase Chain Reaction (RT-gPCR), the expression of SOX10, c-Jun, P75NTR and EGR2 was assessed in denervated samples and compared to healthy nerve. Nonparametric smoothing linear regression was implemented to better visualise trends in the expression of these markers across denervated samples.

It was found, first, that two major genes associated with repair Schwann cells in rodents, c-Jun and p75NTR, are also up-regulated in acutely injured human nerves, while the myelin associated transcription factor EGR2 is downregulated, observations that encourage the view that rodent models are relevant for learning about human nerve injury. Second, as in rodents, the expression of c-Jun and p75NTR declines during long-term denervation. In rodents, diminishing c-Jun and p75NTR levels mark the general deterioration of repair cells during chronic denervation, a process thought to be a major obstacle to effective nerve repair. The down-regulation of c-Jun and p75NTR reported here provides the first molecular evidence that also in humans, repair cells deteriorate during chronic denervation.
\end{abstract}

Keywords: Peripheral nerve degeneration, Human tissue, Nerve transfer, Muscle reinnervation, Schwann cells

\footnotetext{
* Correspondence: jb.phillips@ucl.ac.uk

${ }^{2}$ Department of Pharmacology, UCL School of Pharmacy, University College London, London WC1N 1AX, UK

${ }^{3} \mathrm{UCL}$ Centre for Nerve Engineering, University College London, London, UK

Full list of author information is available at the end of the article
}

(c) The Author(s). 2020 Open Access This article is licensed under a Creative Commons Attribution 4.0 International License, which permits use, sharing, adaptation, distribution and reproduction in any medium or format, as long as you give appropriate credit to the original author(s) and the source, provide a link to the Creative Commons licence, and indicate if changes were made. The images or other third party material in this article are included in the article's Creative Commons licence, unless indicated otherwise in a credit line to the material. If material is not included in the article's Creative Commons licence and your intended use is not permitted by statutory regulation or exceeds the permitted use, you will need to obtain permission directly from the copyright holder. To view a copy of this licence, visit http://creativecommons.org/licenses/by/4.0/. The Creative Commons Public Domain Dedication waiver (http://creativecommons.org/publicdomain/zero/1.0/) applies to the data made available in this article, unless otherwise stated in a credit line to the data. 


\section{Introduction}

Peripheral Nerve Injury (PNI) results in partial or complete loss of sensory and/or motor function and involvement of sympathetic and pain systems in the body segment involved. A study estimates that the incidence of PNI is 560,000 cases per year in the United States alone [1]. The debilitating effects of PNI are highlighted by the much greater prevalence than incidence which leads to long term disruption in the lives of patients [2].

The cellular and molecular mechanisms that underpin nerve regeneration have been investigated extensively in animal models demonstrating that the plasticity of Schwann cells and their ability to switch to a repair-supportive differentiation state after injury is one of the key reasons for strong regenerative capacity observed in the Peripheral Nervous System (PNS) [3-7].

In rodent models, it has been shown that the failure of motor recovery after chronic denervation (greater than 6 months) is associated with substantially reduced capacity of the distal nerve to support growth of axons [8-10]. After injury, progressive deterioration of denervated nerve and muscle make conditions increasingly antagonistic for regeneration, decreasing the chance of functional recovery [11]. Rodent studies have established that this can largely be attributed to adverse changes in Schwann cells and their associated basal laminae, including reduced expression of repair-supportive molecules and decreasing Schwann cell numbers [12-14]. Although this process is thought to be a major obstacle to effective nerve repair, this progressive loss of regeneration support has not been investigated in detail in humans.

Clinical reports have suggested that optimal functional recovery is dependent upon a sufficient number and quality of axons reaching their target within 1 year following injury [15-18]. After this time period, functional outcomes are poor [18-20]. This same pattern of strong initial regeneration potential followed by declining regenerative capacity during chronic denervation and poor functional outcomes from repair of proximal injuries suggests that the basic biology is likely to be comparable between rodents and humans.

Effective translation of the wealth of animal model data into a human paradigm of nerve regeneration would be of great benefit in the development of improved clinical treatments for nerve injury, but progress is limited by ethical and practical challenges associated with studying human nerve injury [21, 22]. Moreover, the intricate anatomy and diverse range of injuries make PNI a heterogeneous pathology to study.

To address this challenge, this study retrieved nerve samples from patients undergoing treatment for nerve injuries at a range of times from injury from acute to chronic. Many nerve samples were retrieved from nerve transfer surgeries. This procedure is deployed by the reconstructive nerve surgeon following complex proximal nerve injuries or those where there has been a significant delay from injury to treatment. The damaged nerves were identified and characterised using intra-operative neurophysiological monitoring to record Compound Nerve Action Potentials (CNAPs). In line with current practice $[23,24]$, the nerve was assumed to be denervated if a CNAP and muscle twitch were absent. The surgeon identified and isolated a suitable donor fascicle and created a neurotmesis injury in order to redirect previously uninjured axons to grow into the chronically denervated stump. The Oberlin's procedure is an example of a nerve transfer which is commonly used to reanimate elbow flexion (Fig. 1a) $[17,25,26]$. A nerve autograft is another surgical technique which can be deployed to reconstruct a nerve gap where the timing and local tissue conditions allow. For this the medial cutaneous nerve of the arm or the sural nerve are commonly utilised as the donor (Fig. 1b) [27]. In cases where significant time (greater than 1 year) has passed since the initial nerve injury, a Free Functioning Muscle Transfer (FFMT) is often the only technique to restore movement (Fig. 1c) [27]. This involves identifying a suitable donor muscle as well as its neurovascular bundle and grafting it in order to restore a function considered to be more pertinent to the quality of life of the patient. All of these surgical protocols liberate excess tissue (both healthy and denervated samples) for study in the laboratory, that would otherwise be disposed of. Across our cohort, samples from various time points during chronic denervation were harvested, allowing the time course of any phenotypic changes in denervated nerve tissue to be explored for the first time. In rodent models, Schwann cells reprogram to a transient pro-regenerative phenotype, the 'repair Schwann cell'. Therefore, in the present study we analysed key markers linked with the transition to the repair Schwann cell phenotype, c-Jun, p75 Neurotrophin receptor (NTR) and early growth response protein 2 (EGR2/KROX20), in addition to a pan-Schwann cell maker, SOX10.

Upregulation of the transcription factor c-Jun in Schwann cells follows nerve injury and amplifies a cascade of downstream changes in expression associated with the phenotypic shift of Schwann cells from a normal myelinating or Remak phenotype to a repair phenotype [28]. Other well-characterised changes associated with Schwann cell reprogramming following injury in rodents include upregulation of p75NTR and downregulation of the transcription factor EGR2 which is associated with myelination [29-32]. SOX10 is a transcription factor constitutively expressed in Schwann cells and has a crucial role in neural crest development, glial cell development and myelin formation and maintenance [33- 
A)

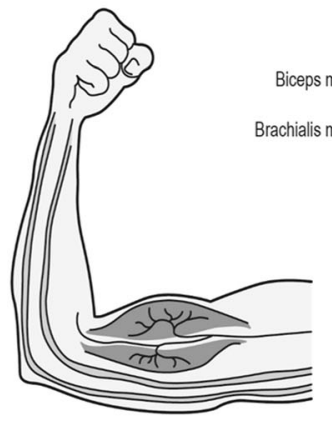

1)

1)

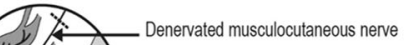

B)

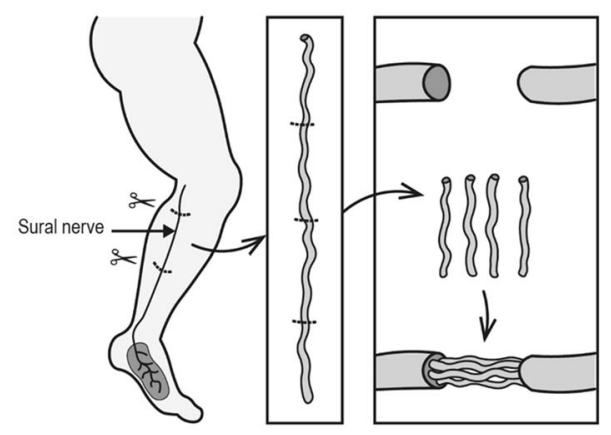

c)

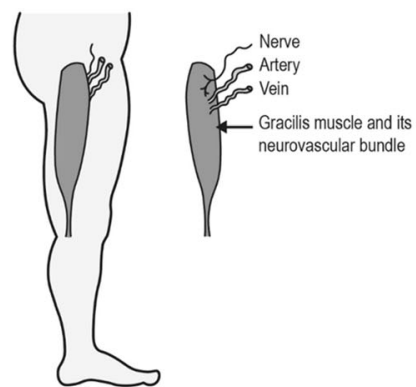

Fig. 1 Reconstructive nerve procedures. a The double Oberlin's nerve transfer is commonly deployed to restore elbow flexion. The surgeon identifies suitable donor fascicles of the ulnar and median nerve that supply wrist flexor muscles. The fascicles are divided and redirected to grow into the denervated musculocutaneous nerve to biceps and brachialis. b Nerve autograft is deployed in larger nerve gaps. The sural nerve is often harvested as the donor nerve and grafted to restore continuity across the damaged nerve trunk. c Free functional muscle transfer (FFMT) is deployed in chronic nerve injuries. This involves identifying a suitable donor muscle and its neurovascular bundle (such as the gracilis) and grafting it to the injured site of nerve damage (often to the upper limb to restore elbow flexion)

36]. It serves as a marker to specifically identify Schwann cells in nerve samples [34, 37, 38]. Expression of this panel of four markers was determined in the denervated human nerve samples and compared with healthy control human nerve tissue at the level of gene expression (Real-Time quantitative Polymerase Chain Reaction, RTqPCR) and tissue protein presence as well as distribution was quantified using immunohistochemistry.

\section{Methods and materials}

Informed consent was obtained according to the declaration of Helsinki [39]. Ethical approval for this project was provided by the UCL Biobank Research Committee (REC 15.15). Twenty-seven patients who underwent reconstructive nerve procedures (nerve transfer, FFMT and nerve autograft) were included. The demographics of the patients identified and included in this study are outlined in Table 1. The innervation status of all nerve samples was determined by intra-operative neurophysiology; if a CNAP and muscle twitch was absent, the nerve was judged to be denervated. Nerve samples were obtained during the course of the surgical procedure, then processed for immunohistochemistry and/or RT-qPCR analysis. Since many of the patients had suffered global plexus injuries, healthy nerve samples were only included if they were retrieved from sites external to the injury site (the affected upper limb) to ensure the sample was not damaged.

\section{Immunohistochemistry \\ Staining protocols}

Samples liberated from reconstructive surgical nerve procedures were immediately fixed in $10 \%$ formalin and then embedded orthogonally in paraffin wax. Serial cross-sections were cut $(3 \mu \mathrm{m})$ using a microtome and immunostaining for neurofilament, SOX10, c-Jun, p75NTR and EGR2 performed.

All staining was carried out using the Leica Bond III automated immunostaining platform, using Leica Bond Polymer Refine Detection with a 3,3'-Diaminobenzidine (DAB)/horseradish peroxidase (HRP) chromogen (Leica, DS9800), with incubations at ambient temperature unless otherwise specified. Dewax was carried out on-board using Leica Bond Dewax solution (Leica, AR9222). Washes were performed between each step using Leica Bond Wash (Leica, AR9590). DAB was enhanced using $0.5 \%$ copper sulphate following application for $10 \mathrm{~min}$.

After on-board heat-induced epitope retrieval (HIER) with Leica Epitope retrieval solution 2 (Leica ER2, high $\mathrm{pH}, \mathrm{AR} 9640$ ) for $20 \mathrm{~min}$ at $99^{\circ} \mathrm{C}$, primary antibodies were applied using the following dilutions (using Leica 


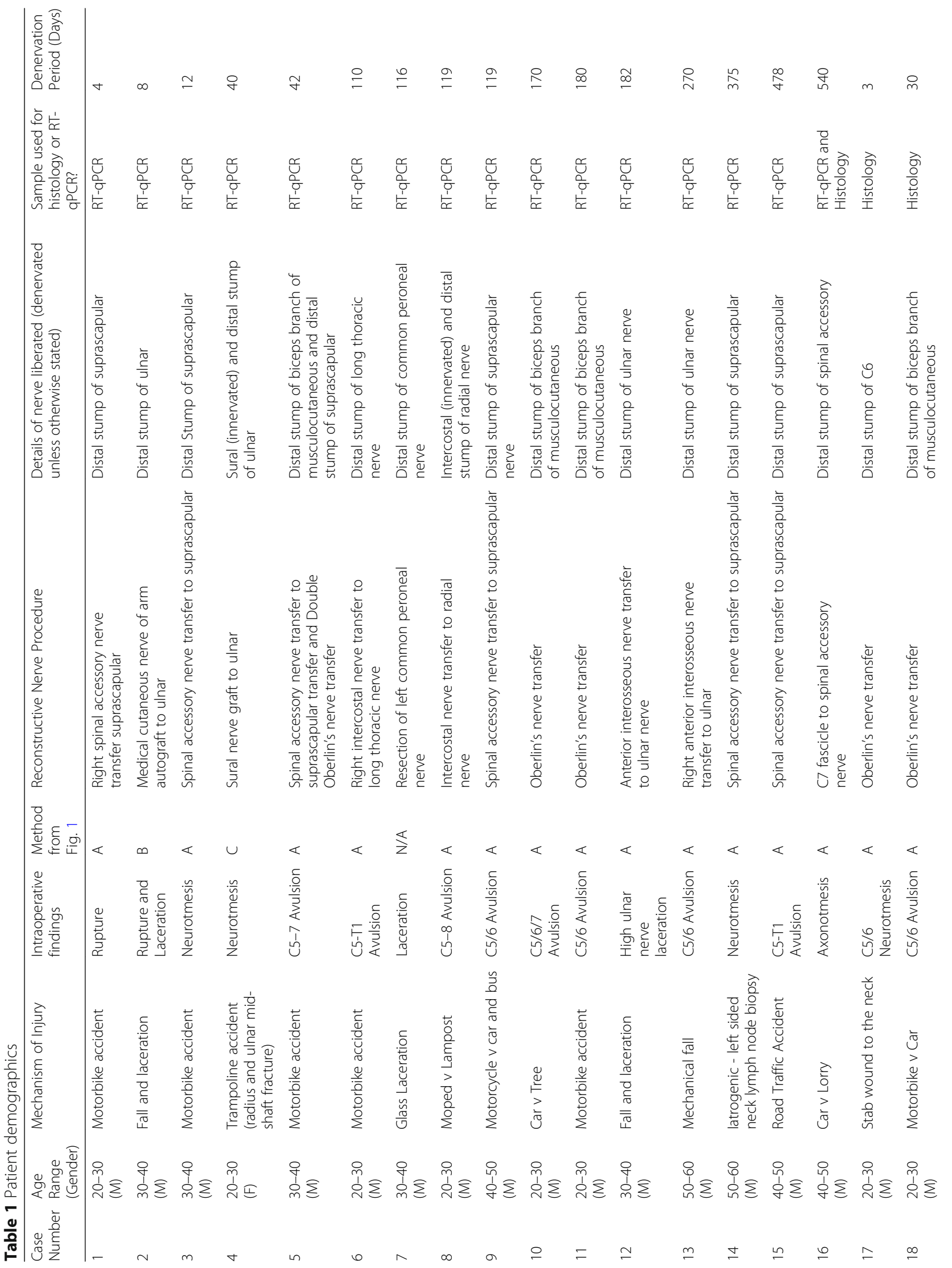




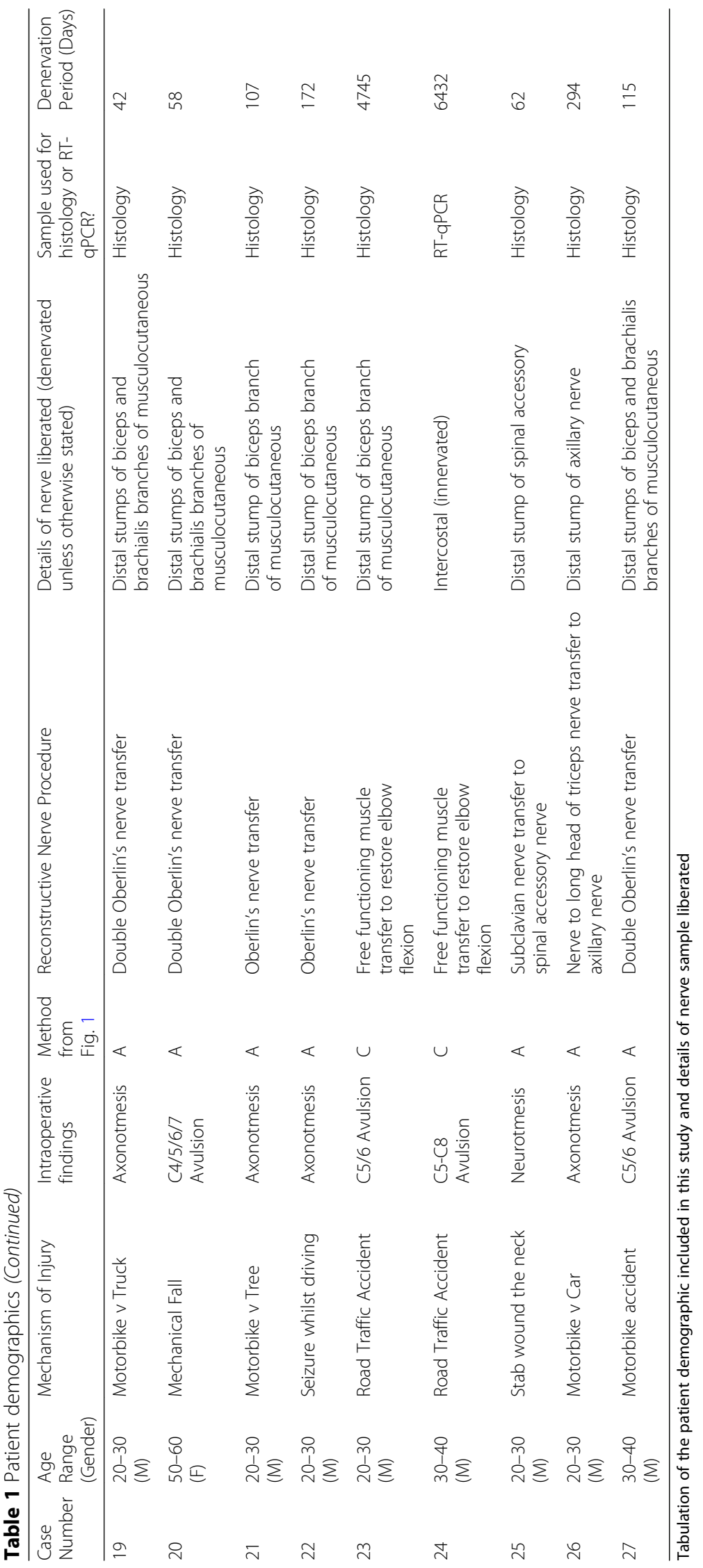


Bond Primary Antibody Diluent (Leica, AR9352)) at ambient temperature: c-Jun (rabbit monoclonal 16A8, Cell Signalling Technologies \#9165, 1:500 for $30 \mathrm{~min}$ ), EGR2 (goat polyclonal, AbCam ab63943, 1:200 for $15 \mathrm{~min}$ ), neurofilament (NF200 mouse monoclonal N52.1.7, Leica Biosystems PA0371, applied as supplied for $15 \mathrm{~min}$ ). For the SOX10/p75NTR co-stain, the SOX10 primary antibody was added first (rabbit monoclonal EP268, CellMarque 383R-15, 1:200 for $15 \mathrm{~min}$ ) followed by p75NTR (rabbit polyclonal, Novus Biologicals NBP1-85769, 1:400 for $30 \mathrm{~min}$ ). The Leica Bond Polymer Refine Detection system (Leica, DS9800) was used for post-primary treatment of all the sections. For the SOX10/p75NTR costain, the Leica Bond Polymer Refine Red detection system (Leica Biosystems, DS9390) was utilised in addition. The staining signal for SOX10 and p75NTR was distinguished by nucleus and cytoplasm localisation respectively.

All immunohistochemistry protocols were validated using positive controls (documented in the Supplementary Fig. 1a, b, c and d).

\section{Image capture and quantification}

Micrographs were captured using the Leica ATC2000. The total cell count was quantified by manually counting the total number of haematoxylin positive cells within each fascicle using ImageJ software [40]. This provided a value for the number of cells per $\mathrm{mm}^{2}$. Similarly, the total number of SOX10 positive cells within each fascicle was also calculated to quantify the number of Schwann cells per $\mathrm{mm}^{2}$.

In order to assess the presence of c-Jun, p75NTR and EGR2 immunoreactivity in Schwann cells, doublestained sections or adjacent serial sections were quantified in the same way and related to the number of Schwann cells per $\mathrm{mm}^{2}$. The number of neurofilament positive fibres within each fascicle was also determined to calculate the axon density (axons per $\mathrm{mm}^{2}$ ) for each nerve sample.

\section{RT-qPCR}

\section{RNA extraction protocol}

The surgical environment affords a number of challenges to the isolation of RNA from nerve samples in sufficient quantities and qualities for downstream RTqPCR assays [21, 22, 41]. In concordance with experimental findings that have characterised the effect of peri-operative variables on the quality and quantity of RNA isolated from human peripheral nerve samples [22], this study minimised the time delay between surgical liberation and cryopreservation as well as minimising the exposure of samples to surgical antiseptics wherever possible.

Each human nerve sample was placed into a $5 \mathrm{ml}$ tube and snap frozen in liquid nitrogen. RNA was isolated from all nerve samples using the Qiagen $\mathrm{RNeasy}^{\circ} \mathrm{Fi}$ brous Tissue Mini Kit. The Cole-Palmer ${ }^{\bullet}$ LabGEN 125 tissue homgenizer with Cole-Parmer LabGEN ${ }^{\bullet}$ RotorStator Generator, Fine, $75 \mathrm{~mm} \times 5 \mathrm{~mm}$ was used to homogenise samples. The quantity of RNA was determined using a Tecan $^{\text {Tx }}$ Infinite 200 PRO multimode reader. Quality of RNA was measured using a NanoDrop ${ }^{\mathrm{Tm}}$ spectrophotometer to ascertain 260/280 ratios for each sample. Samples were also analysed using Biorad Experion $^{\mathrm{mm}}$ RNA analysis kits to assess Ribosomal Integrity Number (RIN), obtain electropherogram data and automated agarose gel readings from samples using the Experion ${ }^{\text {tw }}$ Automated Electrophoresis System. Samples that did not have $260 / 280$ ratios between 1.8 and 2.1 were excluded.

\section{RNA to CDNA synthesis}

In order to convert RNA to complementary DNA (cDNA), the Qiagen whole genome reverse transcription (RT) kit was utilised. The isolated RNA in solution was thawed on ice (within 1 week of RNA isolation from the nerve sample). A minimum of $10 \mathrm{ng}$ of RNA (in 1-5 $\mu \mathrm{l}$ of RNase free water) was added to a microcentrifuge tube. The resulting volume of RNA was adjusted to equate to $5 \mu \mathrm{l}$ by adding RNase free water. The RT mix was then prepared using the T-Script Buffer and T-Script enzyme in a ratio of $4: 1$ respectively. A total of $5 \mu \mathrm{l}$ of this RT mix was added to the $5 \mu \mathrm{l}$ solution of RNA. This mix was then placed into a thermocycler (Applied Biosystems SimpliAmp ${ }^{\mathrm{m}}$ Thermal Cycler) and incubated at $37^{\circ} \mathrm{C}$ for $30 \mathrm{~min}$. After this time period, the reaction was terminated by incubating the mix at $95^{\circ} \mathrm{C}$ for $5 \mathrm{~min}$ followed by cooling to $22^{\circ} \mathrm{C}$.

Table 2 Primer sequences

\begin{tabular}{lll}
\hline Gene & Forward Sequence & Reverse Sequence \\
\hline SOX10 & AGGCTGCTGAACGAAAGTGACAAG & ACTTGTAGTCCGGGTGGTCTTTCT \\
C-Jun & TCCAAGTGCCGAAAAAGGAAG & CGAGTTCTGAGCTTTCAAGGT \\
p75NTR & TGAACGACCCCAACAATGTGG & GGCTTTGGTGATACGCTCG \\
EGR2 & TCTTCCCAATGATCCCAGACT & TTACGGATTGTAGAGAGTGGAGT \\
$18 S$ (Housekeeping gene) & CGCGGTTCTATTTTTTGGT & CGGTCCAAGAATTCACCTC \\
\hline
\end{tabular}

A table to show the sequences of forward and reverse primers used in the RT-qPCR assays 
The ligation mix was then prepared using Ligation Buffer, Ligation Reagent, Ligation Enzyme 1 and Ligation Enzyme 2 in a ratio of 6:2:1:1 respectively (and added in this chronology). A total of $10 \mu \mathrm{l}$ of this mix was added to the resultant RT mix and then vortexed. This mixture was then incubated in the thermocycler at $22{ }^{\circ} \mathrm{C}$ for $2 \mathrm{~h}$. The amplification mix was then prepared by mixing REPLI-g Midi Reaction Buffer and REPLI-g Midi DNA Polymerase in a ratio of 29:1 respectively. A total of $30 \mu \mathrm{l}$ of this reaction mix was added to the ligation mix by vortexing and centrifuging briefly. This mixture was then incubated in the thermocycler at $30^{\circ} \mathrm{C}$ for $8 \mathrm{~h}$ (high-yield reaction). After this time period, the reaction was terminated by incubating the mixture at $95^{\circ} \mathrm{C}$ for $5 \mathrm{~min}$. The resultant cDNA was then diluted in RNase free water in a ratio of $1 / 250(2 \mu \mathrm{l}$ of cDNA added to $500 \mu$ l of RNase free water) and stored at $-20^{\circ} \mathrm{C}$ until required for downstream RT-qPCR.

\section{$R T-q P C R$ reaction mix}

Primers for each gene of interest (GOI) and housekeeping gene (HKG) were designed based on the sequences validated at the Harvard Primerbank [42, 43] and supplied by Sigma-Aldrich. The sequences for the forward and reverse primers are shown for each gene in Table 2. All assays were optimised such that the efficiency of the RT-qPCR reactions was between 90 and $110 \%$ in concordance with published guidelines [44, 45].

All reaction components were thawed on ice then mixed and briefly centrifuged until the reagents were at the bottom of the tubes. To set up the RT-qPCR reactions a MasterMix was made up of $10 \mu \mathrm{L}$ of PowerUp ${ }^{\mathrm{mm}}$ SYBR $^{\text {min }}$ Green MasterMix (2X), $2.5 \mu \mathrm{L}$ of each forward and reverse $(100 \mathrm{mM}$ solution) primer and $5 \mu \mathrm{L}$ of DNA template diluted in RNase free water $(20 \mu \mathrm{L} / \mathrm{Well})$. Sufficient MasterMix was made to run assays for GOI and HKG for each sample in triplicate. MasterMix was made up as $\mathrm{n}+1$ to allow for pipetting errors. This mixture was transferred into a 96-well optical plate (Thermofisher AB-0800).

In all reaction well plates, no template negative controls (NTC) were run along with 2 control samples (sural and two intercostal nerve samples from case numbers 4,8 and 24 respectively shown in Table 1 ). For the NTC reactions, $5 \mu \mathrm{l}$ of RNase free water was added to the well instead of cDNA template. The optical well plate was sealed with a MicroAmp ${ }^{\text {max }}$ Adhesive Optical Cover and briefly centrifuged to ensure reagents were collected at the bottom of the plate. The plate was then transferred into the Applied Biosystems (Thermofisher QuantStudio $^{\text {tx }} 3$ System) to run the RT-qPCR assay using the following thermocycling parameters: an initial denaturation stage to $94{ }^{\circ} \mathrm{C}$ for 2 min followed by 40 cycles of heating to $94{ }^{\circ} \mathrm{C}$ for $15 \mathrm{~s}$ (denaturation), $60{ }^{\circ} \mathrm{C}$ for $1 \mathrm{~min}$ (annealing, extension and read fluorescence).

\section{Quantification}

The Livak [46] method of quantification was used to determine the relative gene expression by characterising the differential between threshold cycle $\left(\mathrm{C}_{\mathrm{T}}\right)$ values for the endogenous control (18S) $\left(\mathrm{C}_{\mathrm{T}: \mathrm{e}}\right)$ and the calibrator (sural/ intercostal nerve) sample $\left(\mathrm{C}_{\mathrm{T}: \mathrm{c}}\right)$. $18 \mathrm{~S}$ was selected as the HKG as it has been shown to be consistently expressed across different human Schwann cell phenotypes [47].

Relative Quantification $(\mathrm{RQ})=2^{-\Delta \Delta \mathrm{CT}}$

with

$$
\Delta \Delta \mathrm{C}_{\mathrm{T}}=\Delta \mathrm{C}_{\mathrm{T}}-\mathrm{C}_{\mathrm{T}: \mathrm{c}}
$$

and

$$
\Delta \mathrm{C}_{\mathrm{T}}=\mathrm{C}_{\mathrm{T}}-\mathrm{C}_{\mathrm{T}: \mathrm{e}}
$$

\section{Statistical analysis}

Nonparametric smoothing linear regression was applied to immunohistochemistry and RT-qPCR data to allow improved visualisation of the trends presented in the data. More details on how this was performed is provided in the supplementary material.

\section{Results}

Thirty four denervated and five healthy nerve samples were included in the study, from 26 males and one female. The mean patient age at the time of surgery was $34( \pm 6)$ years. The median time between injury and surgery was 116 days (ranging from 4 to 6432 days). A total of 64 nerve samples were retrieved from surgery over a 3 year period. However, 25 samples (39\%) were rejected from the study due to one of the following reasons:

1) Fourteen samples yielded insufficient quantity and/ or quality of RNA for RT-qPCR analysis.

2) Seven of the samples were of insufficient quantity for sectioning.

3) Four of the samples presented an inappropriate morphology for sectioning.

For immunohistochemistry, a total of two independent nerve samples with no known pathology were retrieved as a baseline (Case number 4 and 8 as described in Table 1). The size of the intercostal nerve sample from Case number 24 (Table 1) was insufficient for immunohistochemical analysis. Quantification of immunohistochemistry suggested that across the two healthy nerve samples, the density of SOX10 cells as well as expression levels of each of the phenotypic markers c-Jun, p75NTR and EGR2 was similar $\left(1872 \pm 258 \mathrm{~mm}^{2}, 193 \pm 19 \mathrm{~mm}^{2}, 76 \pm 14 \mathrm{~mm}^{2}\right.$ and $1555 \pm$ 


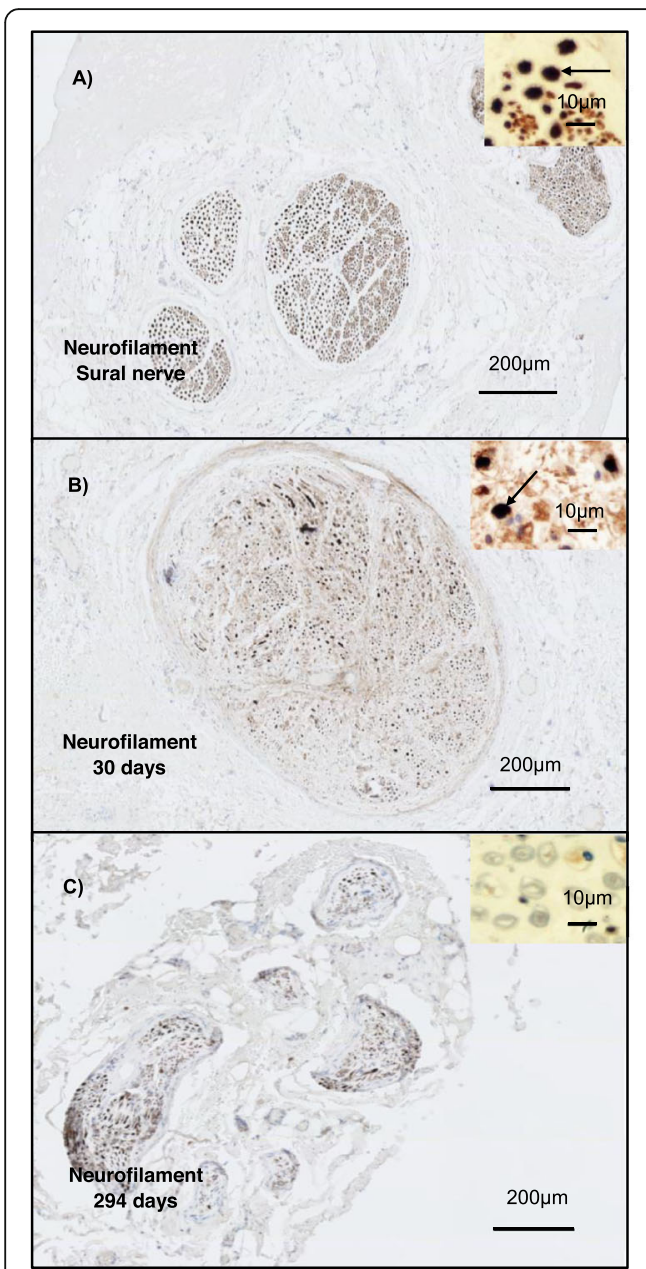

D)

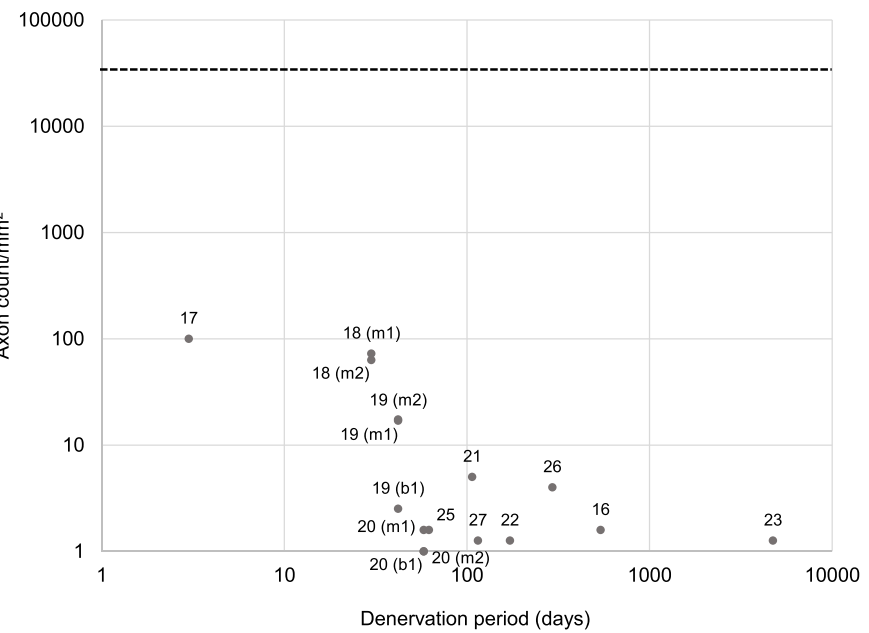

E)

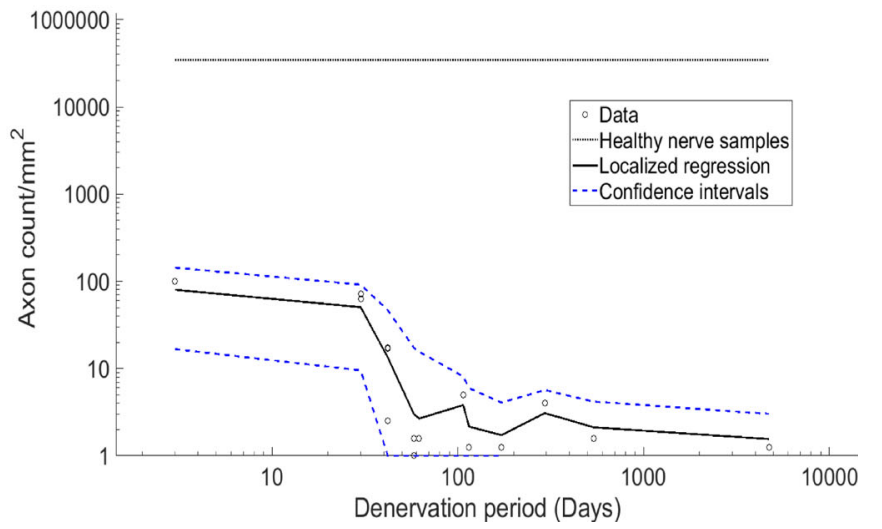

Fig. 2 Immunohistochemical detection of neurons in healthy and denervated human nerves. a- c represent nerve cross sections stained for neurofilament (brown) with haematoxylin and eosin stain. The black arrow in the micrograph represents positive neurofilament staining. In $\mathbf{d}$ and $\mathbf{e}$ the black dotted line represents the mean number of axons detected in healthy nerve samples (case number 4 and 8). The $x$-axis is Log (denervation time in days). a Healthy sural nerve. b Biceps branch of the musculocutaneous nerve denervated for 30 days. c Axillary nerve denervated for 294 days with deteriorated morphology. $\mathbf{d}$ A scatter plot to represent Log (axon count $/ \mathrm{mm}^{2}$ ) against denervation time. e Nonparametric smoothing linear regression of the Log (axon count $/ \mathrm{mm}^{2}$ ) against denervation time. Case numbers are attached to each data point for reference to Table 1 with descriptors of whether the sample was collected proximally or distally: $m 1$ - Proximal part of the denervated stump of the biceps branch of musculocutaneous nerve. $m 2$ - Distal part of the denervated stump of the biceps branch of musculocutaneous nerve. b1 - Proximal section of the denervated stump of the brachialis branch of musculocutaneous nerve. 51 - Denervated stump of suprascapular nerve. sal - Proximal section of the denervated stump of the spinal accessory nerve. sa2 - Distal section of the denervated stump of the spinal accessory nerve

$45 \mathrm{~mm}^{2}$ respectively) (Supplementary Fig. 2). Moreover, axon density was similar in sural and intercostal nerve samples $\left(34,567 \pm 1107 \mathrm{~mm}^{2}\right)$ (Supplementary Fig. 3).

For RT-qPCR, a total of three independent nerve samples with no known pathology were retrieved as baseline controls (one sample of sural nerve (Case number 4) and two samples of intercostal nerve (Case number 8 and 24) as shown in Table 1). The mean relative gene expression in these control samples (where $\Delta C_{T}=C_{T}-C_{T: e}$ ) of the SOX10, c-Jun, p75NTR and EGR2 (Supplementary Fig. 4) was relatively similar across the healthy nerve samples $(13.26 \pm 1.89,10.78 \pm 0.42,12.55 \pm 1.62,8.96 \pm 0.81$ respectively). Immunohistochemical detection of axons in the damaged samples using neurofilament antibodies revealed that the large majority of samples contained fewer than 10 axons (Fig. 2) beyond 40 days of denervation.

Immunohistochemistry followed by quantitative analysis of micrographs showed how the number and phenotype of Schwann cells within the denervated samples varied according to denervation time, compared with normal healthy nerve controls. To account for variations in the dimensions of nerves between individuals, cross-sections were quantified in terms of the intrafascicular density of cells, expressed as immunoreactive cells per $\mathrm{mm}^{2}$ cross-sectional area. It is clear from Fig. 3a and $\mathrm{b}$ that the total cell density (haematoxylin positive 


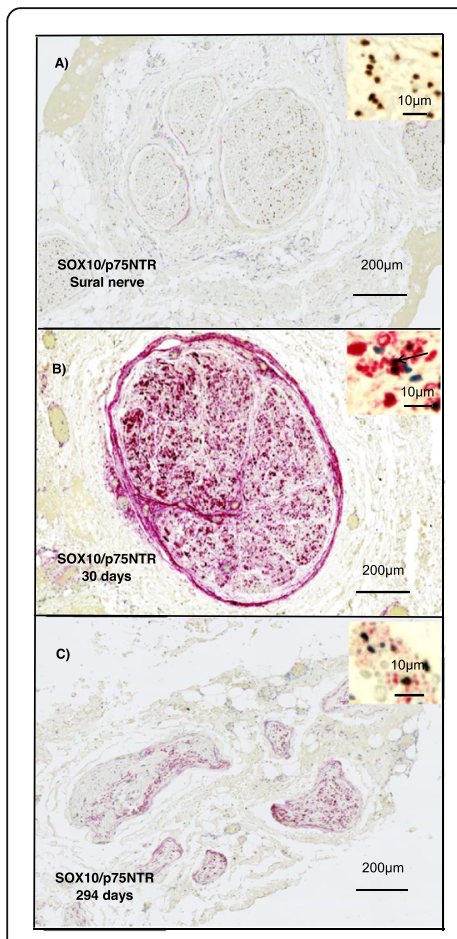

D)
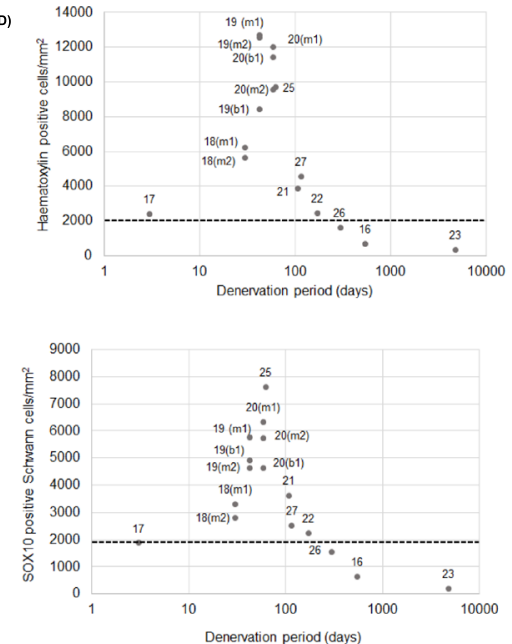

H)

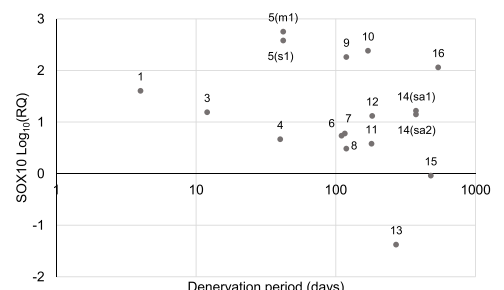

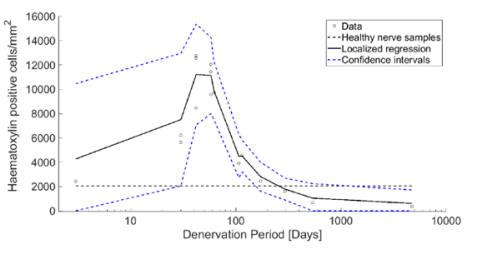

G)
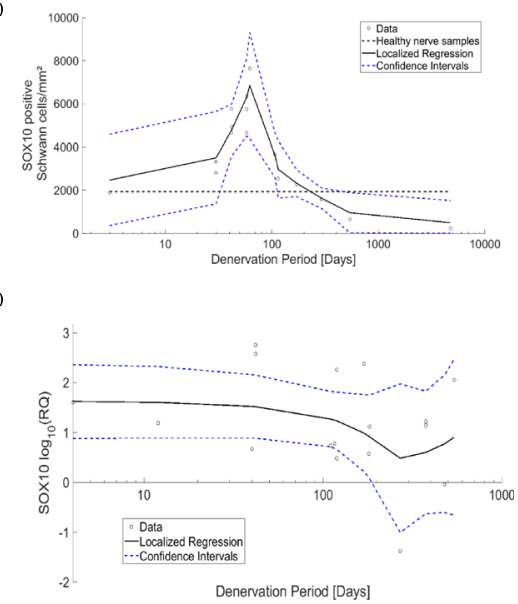

Fig. 3 Immunohistochemical and RT-qPCR analysis of Schwann cells in healthy and denervated human nerves. a-c represent nerve cross sections immunostained for SOX10 (brown) and P75 p75NTR (red) along with haematoxylin and eosin stain. The black arrow in the micrographs indicates a SOX10/p75NTR positive Schwann cell. $\mathbf{d}$-i the x-axis represents Log (denervation time in days). In $\mathbf{d}$-g, the horizontal black dotted line represents the mean value obtained for the healthy nerve group. a Healthy sural nerve $\mathbf{b}$ Biceps branch of the musculocutaneous nerve denervated for 30 days. The brown staining represents a SOX10 positive nucleus whilst the red cytoplasmic staining represents p75NTR positive staining. c Axillary nerve denervated for 294 days with deteriorated morphology. d Scatter plot to represent the total number of haematoxylin positive cells $/ \mathrm{mm}^{2}$ in denervated samples. e Nonparametric smoothing linear regression of the total number of haematoxylin positive cells/mm ${ }^{2}$ in denervated samples. $\mathbf{f}$ Scatter plot to represent the total number of Schwann cells $/ \mathrm{mm}^{2}$ across denervated samples $\mathbf{g}$ Nonparametric smoothing linear regression of the total number of SOX10 positive Schwann cells $/ \mathrm{mm}^{2} \mathbf{h}$ RT-qPCR analysis of SOX10 mRNA expression across denervated samples. i Non-parametric smoothing linear regression of the SOX10 RT-qPCR data. Case numbers are attached to each data point for reference to Table 1 with descriptors of whether the samples were collected proximally or distally: $m 1$ - Proximal part of the denervated stump of the biceps branch of musculocutaneous nerve. $m 2$ - Distal part of the denervated stump of the biceps branch of musculocutaneous nerve. b1 Proximal section of the denervated stump of the brachialis branch of musculocutaneous nerve. s1 - Denervated stump of suprascapular nerve. sal - Proximal section of the denervated stump of the spinal accessory nerve. sa2 - Distal section of the denervated stump of the spinal accessory nerve

cells) increased after injury to reach a peak after about 90-100 days of denervation. Compared to healthy control nerves, cell density was elevated in samples that were denervated for up to 200 days then this density decreased to lower than healthy controls in the more chronically denervated samples. SOX10 positive Schwann cells represented approximately half of the total number of haematoxylin positive cells in most cases (Fig. 3c and d). The density of SOX10-positive cells also peaked at 90-100 days and then decreased as seen using haematoxylin labelling. In contrast to that seen in injured nerves, the large majority of cells in healthy nerve samples were found to be SOX10 positive.

However, RT-qPCR analysis of SOX10 mRNA expression did not mirror the injury-induced increases in cell density at 90-100 days described above. Instead, SOX10 was upregulated above baseline in all but two of the denervated samples. A trend towards decreasing SOX10 levels was, however, seen after 100 days of denervation (Fig. 3e and f).

With immunohistochemistry analysis, the number of Schwann cells per $\mathrm{mm}^{2}$ showing positive expression of nuclear c-Jun was elevated in the denervated nerves, particularly between 10 and 100 days denervation (Fig. 4a, b, c, d and e). Peak expression was seen at 90-100 days co-incident with the peaks of total cell density and density of SOX10 positive cells. The level of Schwann cell cJun expression declined to levels similar to or lower than that of uninjured nerves by around 500 days of denervation (Fig. 4d and e). The RT-qPCR data were comparable, showing that c-Jun expression was increased approximately 140 -fold in the samples with the shortest 


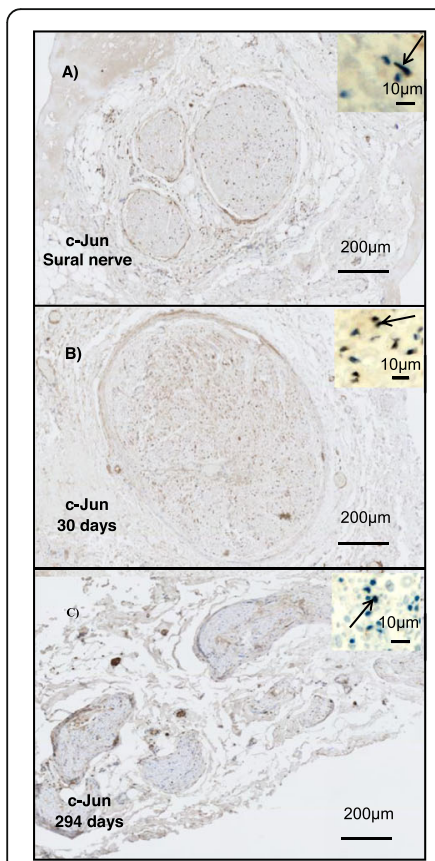

D) 8000
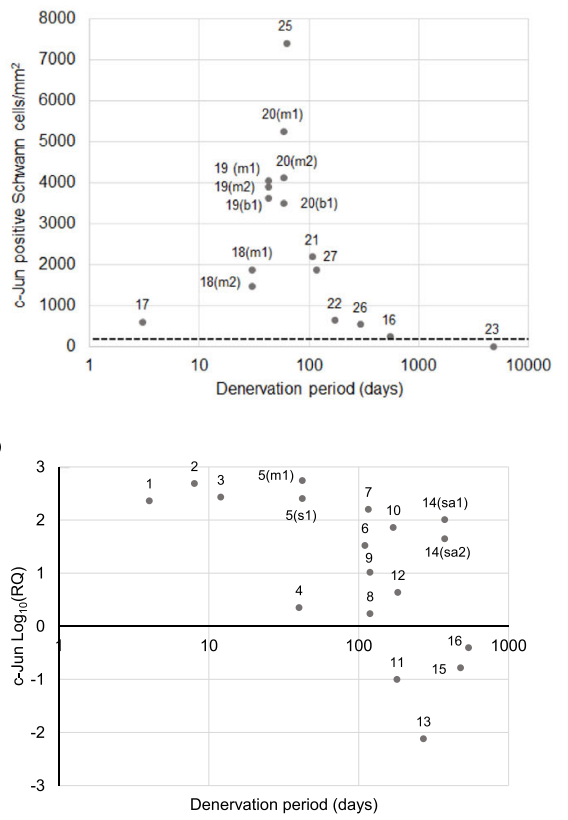

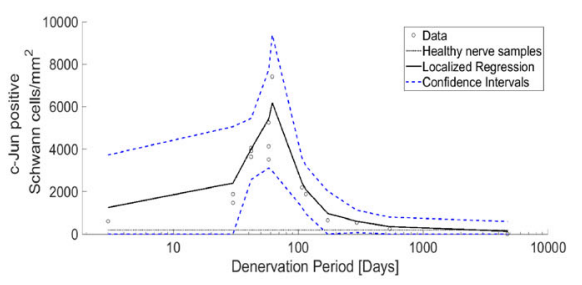

G)

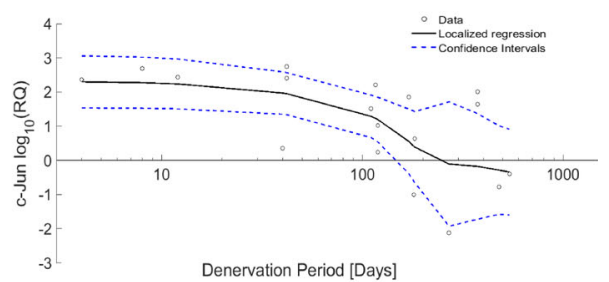

Fig. 4 Immunohistochemistry and RT-qPCR analysis of c-Jun in healthy and denervated human nerves. a-c represent nerve cross sections immunostained for c-Jun (brown) along with haematoxylin and eosin stain. The black arrow in the micrographs indicates a c-Jun positive Schwann cell. The $\mathrm{x}$-axis in $\mathbf{d}$-g represents Log (denervation time in days). In $\mathbf{d}$ and $\mathbf{e}$ the horizontal black dotted line represents the mean value obtained for the healthy nerve group. a Healthy sural nerve. b Biceps branch of the musculocutaneous nerve denervated for 30 days. c Axillary nerve denervated for 294 days with deteriorated morphology. d A scatter plot to represent the total number of c-Jun positive Schwann cells/ $\mathrm{mm}^{2}$ in denervated samples. e Nonparametric smoothing linear regression of the total number of c-Jun positive Schwann cells/mm². $\mathbf{f}$ RT-qPCR analysis of c-Jun mRNA expression across denervated samples. g Nonparametric smoothing linear regression of the c-Jun RT-qPCR data. Case numbers are attached to each data point for reference to Table 1 with descriptors of whether the samples were collected proximally or distally: $m 1$ - Proximal part of the denervated stump of the biceps branch of musculocutaneous nerve. $m 2$ - Distal part of the denervated stump of the biceps branch of musculocutaneous nerve. $b 1$ - Proximal section of the denervated stump of the brachialis branch of musculocutaneous nerve. 1 - Denervated stump of suprascapular nerve. sa1 - Proximal section of the denervated stump of the spinal accessory nerve. sa2 - Distal section of the denervated stump of the spinal accessory nerve

denervation period (4-50 days) and was also increased (to a slightly lesser extent) in most samples up to 200 days (Fig. $4 \mathrm{f}$ and g). Beyond this time point c-Jun expression declined, and there was a trend for some of the nerve samples to have c-Jun expression levels lower than the healthy nerve baseline (Fig. $4 \mathrm{f}$ and g).

p75NTR demonstrated a similar trend, with immunohistochemistry analysis showing the number of p75NTR positive Schwann cells per $\mathrm{mm}^{2}$ to be elevated particularly between 10 and 100 days of denervation followed by a decline after more than around 80 days of denervation (Fig. 5a, b, c, d and e). The RT-qPCR data were comparable, showing that samples denervated for between 4 and 170 days demonstrated an increase in p75NTR mRNA expression of 10- to 100-fold compared to uninjured nerves. p75NTR expression in most samples that had been denervated for longer declined towards and eventually below baseline (Fig. $5 \mathrm{f}$ and g).

Moreover, it was found from the immunohistochemistry and RT-qPCR results that samples collected more distally yielded lower levels of c-Jun and p75NTR than those harvested more proximally (Figs. $4 \mathrm{~d}$ and f, $5 \mathrm{~d}$ and f).

EGR2 expression identified using immunohistochemistry was lower than baseline in nearly all samples, as expected from the involvement of this transcription factor in myelination (Fig. 6a, b, c, d and e). Beyond 1 month of denervation, the proportion of EGR2 positive Schwann cells demonstrated an overall decrease until reaching almost 0 by around 500 days denervation (Fig. $6 \mathrm{~d}$ and e). RT-qPCR demonstrated a similar trend with most samples demonstrating down-regulation of EGR2 mRNA, by 3000-fold in some cases (Fig. 6f and g).

\section{Discussion}

To help bridge the gap between the extensive studies of rodent Schwann cells in regenerating nerves and their counterparts in injured human nerves, we have examined damaged human nerves for key markers and regulators associated with the rodent Schwann cell injury 


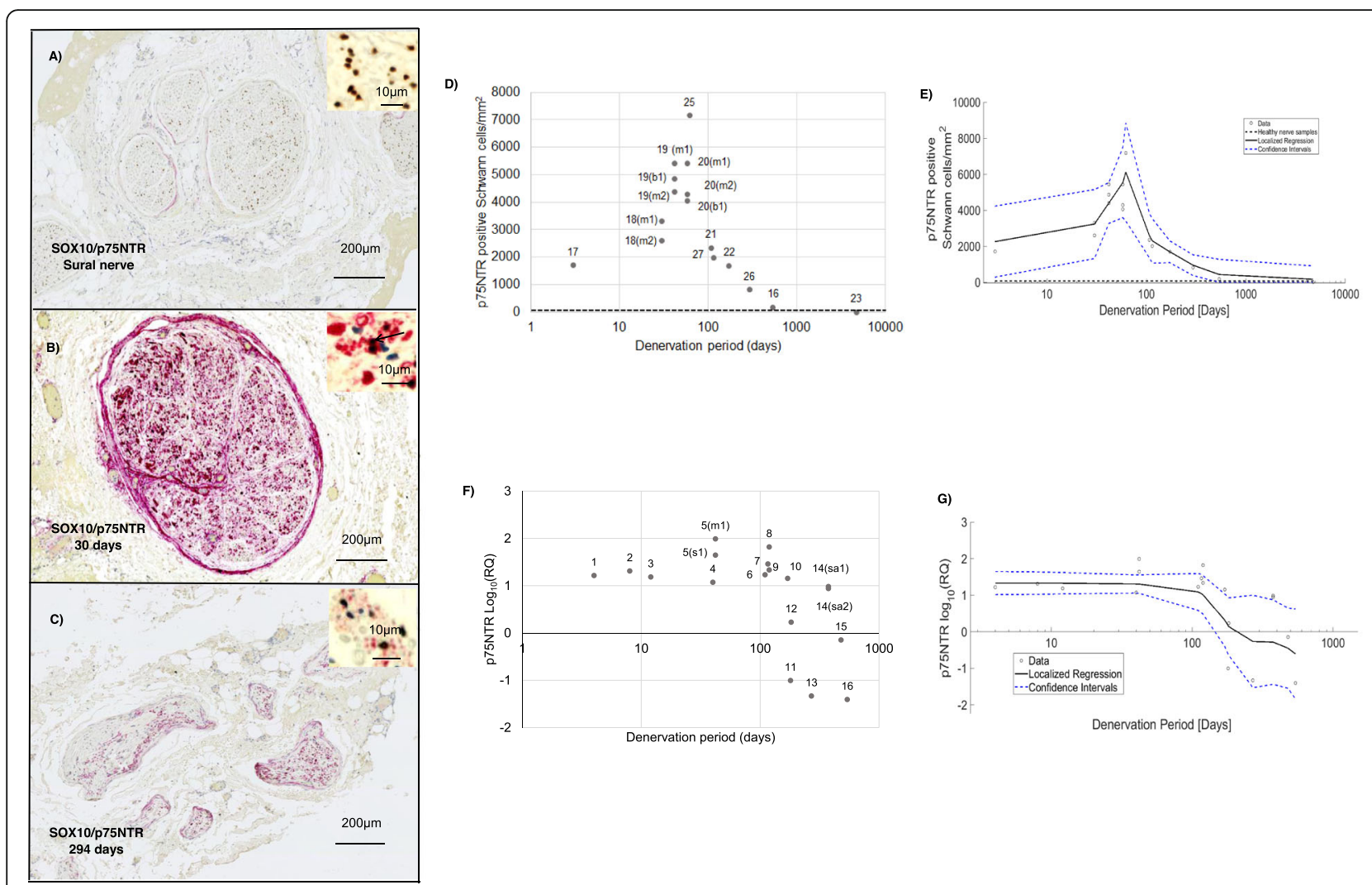

Fig. 5 Immunohistochemistry and RT-qPCR analysis of p75NTR in healthy and denervated human nerves. a-c represent nerve cross sections immunostained for SOX10 (brown) and P75 p75NTR (red) along with haematoxylin and eosin stain. The black arrow in the micrographs indicates a SOX10/p75NTR positive Schwann cell. The $\mathbf{x}$-axis in $\mathbf{d}-\mathbf{g}$ represents Log (denervation time in days). In $\mathbf{d}$ and $\mathbf{e}$ the horizontal black dotted line represents the mean value obtained for the healthy nerve group. a Healthy sural nerve $\mathbf{b}$ Biceps branch of the musculocutaneous nerve denervated for 30 days. The brown staining represents a SOX10 positive nucleus whilst the red cytoplasmic staining represents p75NTR positive staining. c Axillary nerve denervated for 294 days with deteriorated morphology. d A scatter plot to represent the total number of p75NTR positive Schwann cells $/ \mathrm{mm}^{2}$ in denervated samples. e Nonparametric smoothing linear regression of the total number of p75NTR positive Schwann cells $/ \mathrm{mm}^{2}$. f RT-qPCR analysis of p75NTR mRNA expression across denervated samples. $\mathbf{g}$ Nonparametric smoothing linear regression of the p75NTR RT-qPCR data. Case numbers are attached to each data point for reference to Table 1 with descriptors of whether the samples were collected proximally or distally: $m 1$ - Proximal part of the denervated stump of the biceps branch of musculocutaneous nerve. $m 2$ - Distal part of the denervated stump of the biceps branch of musculocutaneous nerve. b1 - Proximal section of the denervated stump of the brachialis branch of musculocutaneous nerve. s1 - Denervated stump of suprascapular nerve. sal - Proximal section of the denervated stump of the spinal accessory nerve. sa2 - Distal section of the denervated stump of the spinal accessory nerve

response. We have paid particular attention to events that take place during chronic denervation of distal nerve stumps, since both in rodents and humans, the deterioration of this tissue during long-term denervation is considered to be an important obstacle to effective nerve repair. For the first time, the markers SOX10, c-Jun, p75NTR and EGR2 have been explored in denervated samples. Moreover, exploration of the markers SOX10, p75NTR and EGR2 in healthy human nerve has been quantified for the first time.

To achieve this objective, this study utilised standardised surgical protocols of human nerve liberation, nerve transfer, autograft and FFMT. Almost $40 \%$ of the total samples retrieved from surgery were rejected from the study due to the tissue being unsuitable for RT-qPCR and/or immunohistochemistry analysis. This reflects the significant challenges associated with retrieving human nerve samples from the surgical environment for study in the laboratory $[22,48]$. The majority of samples were rejected on the basis of insufficient quantities and quality of RNA. This prompted a recent study to optimise handling of samples in the surgical environment [22].

The data on gene and protein expression obtained from the healthy control nerve population in the present study concurs with the rodent literature, and the axon densities are similar to those reported in studies of human sural nerve samples extracted from cadavers [49, 50]. In addition, there was little variation between samples in the expression of the markers of interest (SOX10, c-Jun, p75NTR and EGR2) between healthy nerve 

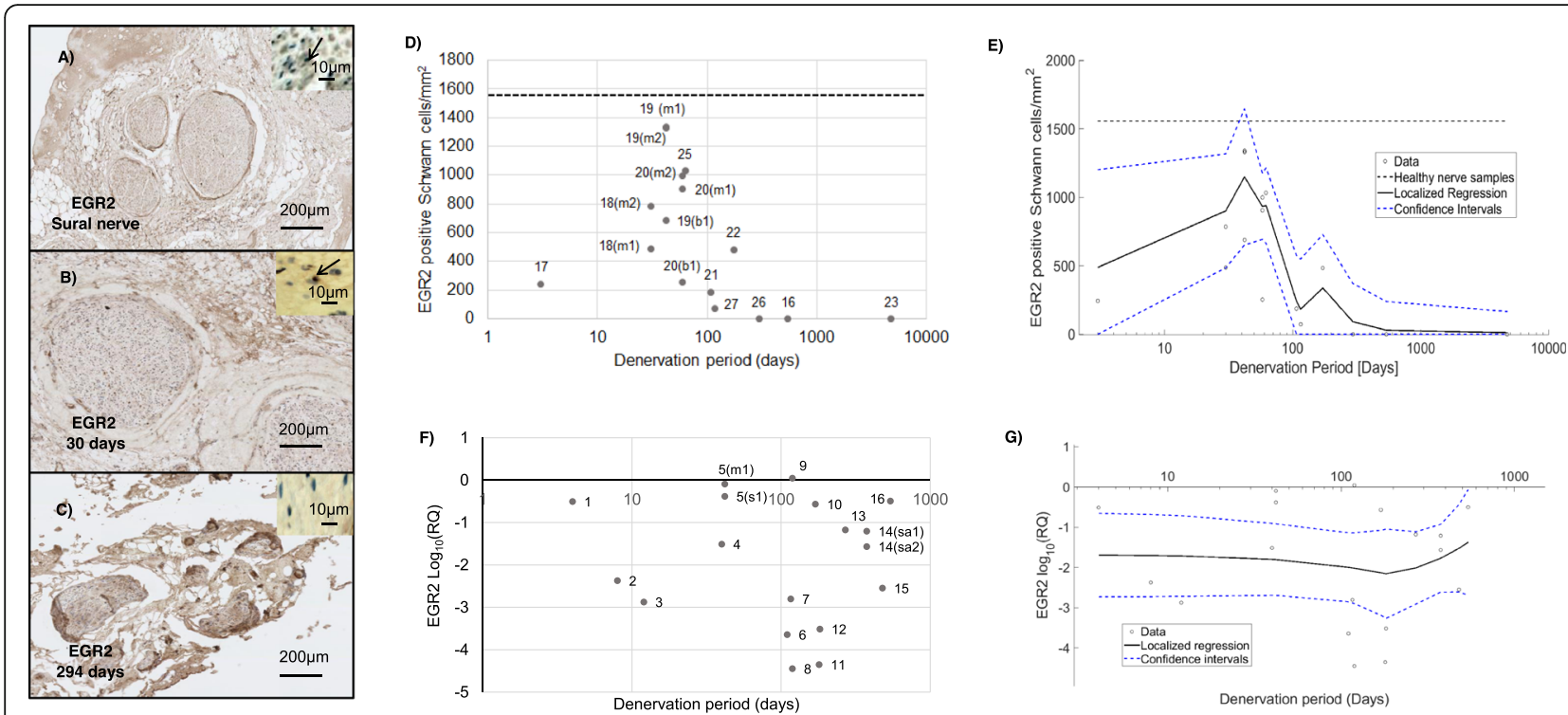

Fig. 6 Immunohistochemistry and RT-qPCR analysis of EGR2 in healthy and denervated human nerves. a-c represent nerve cross sections imunostained for EGR2 (brown) along with haematoxylin and eosin stain. The black arrow in the micrograph indicates a EGR2 positive Schwann cell. The $\mathbf{x}$-axis in $\mathbf{d}$-g represents $\log$ (denervation time in days). In $\mathbf{d}$ and $\mathbf{e}$ the horizontal black dotted line represents the mean value obtained for the healthy nerve group. a Healthy sural nerve. b Biceps branch of the musculocutaneous nerve denervated for 30 days. c Axillary nerve denervated for 294 days with deteriorated morphology. d A scatter plot to represent the total number of EGR2 positive Schwann cells/mm in denervated samples. e Nonparametric smoothing linear regression of the total number of EGR2 positive Schwann cells $/ \mathrm{mm}^{2}$. $\mathbf{f} R T$-qPCR analysis of EGR2 mRNA expression across denervated samples. g Nonparametric smoothing linear regression of the p75NTR RT-qPCR data. Case numbers are attached to each data point for reference to Table 1 with descriptors of whether the samples were collected proximally or distally: $m 1$ Proximal part of the denervated stump of the biceps branch of musculocutaneous nerve. $m 2$ - Distal part of the denervated stump of the biceps branch of musculocutaneous nerve. b1 - Proximal section of the denervated stump of the brachialis branch of musculocutaneous nerve. s1 Denervated stump of suprascapular nerve. sa1 - Proximal section of the denervated stump of the spinal accessory nerve. sa2 - Distal section of the denervated stump of the spinal accessory nerve

samples from different individuals, assessed using quantitative RT-qPCR and immunohistochemistry analysis suggesting that this was a suitable control group.

Rodent studies have shown that nuclear SOX10 immunoreactivity serves as a specific Schwann cell marker, since in peripheral nerves this transcription factor is selectively and constitutively expressed in Schwann cells $[33,34]$. Whilst SOX10 has also been examined in human Schwann cells, this has been largely limited to the study of pathologies such as Schwannoma [36, 51]. The present results show that in healthy human nerve EGR2, c-Jun and p75NTR are expressed in SOX10 positive cells.

Focusing on immunohistochemical detection of axons, it was found that most samples that were denervated beyond 10 days had fewer than 10 axons present. This is consistent with Wallerian degeneration and concurs with neurophysiological reports which have shown that the Compound Muscle Action Potential (CMAP) declines to subnormal and un-recordable levels over 10 days following a nerve injury which has led to the transection of axons $[52,53]$.
In comparing the density of Schwann cells (SOX10 positive cells) between healthy controls and denervated samples, it was found that nerves that had been denervated for about a month showed approximately 4-fold higher densities of Schwann cells compared to baseline levels. This is consistent with the well documented injury-induced proliferation of Schwann cells in rodent nerves [12-14]. Classically, Schwann cell proliferation has been considered important for regeneration, although this has been called into question by more recent results $[54,55]$.

In human nerves denervated for longer periods, we observed and quantified another notable aspect of repair Schwann cell biology previously studied in rodents, namely the steady and dramatic reduction of Schwann cell numbers in the denervated stump. Eventually, at 57 months, the number of cells fell to levels below even those in uninjured nerves. This decline in cell density during chronic denervation was seen both counting total number of cells positive for haematoxylin and counting SOX10 positive cells only. However, a smaller proportion of the total cell population was SOX10 positive in 
the chronically denervated samples. This is likely due to an increase in the non-Schwann cell population associated with Wallerian degeneration such as the infiltration of other cells such as macrophages and other immune cells [56-59], which could be investigated in future studies using additional immunohistochemical markers. The gradual loss of Schwann cells from denervated distal stumps is considered to be a major contributor to the creation of an environment that becomes increasingly antagonistic to regeneration over time [11-14, 60]. Contrary to the histological analysis, SOX10 mRNA remained elevated in all but two of the denervated samples. This discrepancy could be attributable to the use of different nerve samples for RT-qPCR and histology as well as alteration of post-translational regulation of SOX10 in the Schwann cells found in injured nerves.

Focusing on markers of Schwann cell phenotype in injured nerves, the expression of all markers was variable between individuals in contrast to that seen in uninjured control nerves, but there were some overall trends. Some of the variability between individuals could be caused by the number of different mechanisms of injury included in the present study (such as avulsions as well as ruptures and lacerations). Age differences between participants (mean age of $34( \pm 6)$ years) could also affect the results, since rodent data show that the Schwann cell injury response is subdued in aging animals [61].

From animal models it is known that upregulation of c-Jun is a global amplifier of the reprogramming events that take place in Schwann cells following denervation and are critical for successful nerve regeneration $[28,60$, 62]. A key component of this reprogramming is the appearance of a novel set of phenotypes that constitute part of a repair programme, and upregulation of markers that characterise pre-myelinating Schwann cells. p75NTR is one such marker and at the protein level p75NTR has been shown to be regulated by c-Jun. c-Jun and p75NTR are upregulated within hours following injury and continue to increase for a further 7-10 days $[63,64]$. During chronic denervation, the expression of these markers in the distal stump then steadily declines. As c-Jun levels decline, functional outcomes become less favourable, while genetic restoration of c-Jun levels in transgenic mice restores regeneration [11, 65-67]. While the role of p75NTR in regeneration is not clear [68-70], the drop in p75NTR expression during chronic denervation has been used as a marker of repair Schwann cell deterioration [63, 64].

For the first time, this study has shown that a similar pattern of regulation is seen in human nerve regeneration. c-Jun and p75NTR increase in acutely damaged samples (within the first month) and decline in chronically denervated samples. This finding provides new information that can inform the clinical management of nerve-injured patients. Clinical studies suggest that optimal muscle reinnervation is dependent upon a sufficient quantity and quality of motor units being established at the target organ within 1-year following injury [20, 71]. This time-frame has been largely based on the understanding of degenerative changes at the motor endplate and within the denervated muscle [18-20, 72, 73]. Importantly, the present study provides new evidence suggesting that the repair phenotype of Schwann cells also fades over a shorter time period of around 100 days following injury, resulting in an environment increasingly less supportive of regeneration. Moreover, the results show that in human Schwann cells, c-Jun and p75NTR expression are associated, as previously seen in rodents, suggesting that the basic molecular features which underpin nerve regeneration in humans and rodents are comparable.

The changes in the mRNA reported here may also mirror changes at the level of the spinal cord. Animal models have shown that shortly after neural trauma, injury-induced excitation signals are transduced retrogradely from neuronal and non-neuronal cells to their own injured cell body [74]. An array of molecular responses have been identified leading to the dysregulation of neurotrophic factors, neurotrophic receptors, neuropeptides and transcription factors [74]. Specifically, the upregulation of c-Jun and p75NTR and down-regulation of EGR2 represent key changes in the creation of a neuronal phenotype that is supportive of regeneration, which fades over time leading to the reduced regenerative capacity of chronically axotomised axons [74].

The nonparametric linear regression analysis of Schwann cell numbers and c-Jun, p75NTR and EGR2 expression during chronic denervation summarises key temporal changes in repair Schwann cells after injury. With further data this could become a useful tool in assessing and predicting changes associated with denervation in PNI patients. It is notable that the magnitude of the expression fold changes in gene expression between control and damaged human nerves, presented in the RT-qPCR data, are significantly larger than those reported in rodent studies [28, 75-77]. To accommodate this range, the present data are displayed as $\log _{10}(\mathrm{RQ})$ changes, rather than $\log _{2}(\mathrm{RQ})$ changes which are reported in a number of rodent studies [28, 75-77].

Where a sample had been collected and dissected into proximal and distal sections from the same nerve (case [14, 18, 19 and 20]), samples which were collected more distally expressed lower quantities of repair Schwann cell markers (c-Jun and p75NTR) than their more proximal counterparts. This observation, whilst based on a limited number of samples, suggests that Schwann cell phenotype becomes less supportive of regeneration in more 
distal nerve segments, an observation that warrants further exploration.

Down-regulation of the molecular pathways associated with myelination is another key component of the repair programme that is governed by c-Jun in rodents [30, 60, $78,79]$. EGR2 is a marker of myelination and its absence or malfunction has been linked with a number of myelinopathies [29, 31]. The expression of EGR2 was downregulated in all denervated samples presented in this study, indicating reversal of myelin differentiation. This suggests that after injury the molecular machinery of myelination in human Schwann cells is regulated in a similar way to that in rodents.

This study should be interpreted in light of its limitations. Although samples were assumed to be denervated based on intra-operative neurophysiology, a few samples demonstrated some positive neurofilament staining. This is perhaps attributable to neurofilament positive autonomic/afferent fibres. Such axons would not have been detected in the functional screening and would therefore not have been excluded from the study. To a small degree, the presence of these axons may have influenced the local cellular environment, meaning that not all of the Schwann cells will have shifted towards a repair phenotype. In addition, only a small number of healthy nerve samples were used for comparison with denervated samples (three samples for RT-qPCR and two samples for histology). This limitation reflects the ethical and practical challenges associated with obtaining healthy nerve samples. Even when it is possible to retrieve small samples of healthy nerve during surgical procedures, the yield of RNA is often reduced to levels sub-optimal for quantification [22]. In addition, the small size and morphology of these samples can make them inappropriate for histological analysis when complete transverse sections cannot be obtained. A further limitation was that this study only obtained a small number of acutely denervated samples (three samples retrieved less than 30 days following the initial injury). In the general trauma population, nerve injuries often occur secondary to severe vehicular collisions [80, 81] which is reflected in the present study, accounting for 18 out of 27 of injuries (67\%). As a result, many patients present with co-morbidities that require treatment before investigation of a suspected nerve injury, leading to a substantial delay between the initial injury and reconstructive nerve surgery where the samples can be retrieved. In addition, patients are often observed for 3 to 6 months for spontaneous functional recovery following blunt trauma before surgical repair is considered [82]. For these reasons, the retrieval of acutely denervated (less than 10 days between injury and surgery) samples was challenging. This study would also benefit from the inclusion of more samples at standardised time points.
However, this is challenging due to the heterogeneous nature of PNI, the rarity of the injuries as well as the practical and ethical challenges associated with harvesting human nerve tissue for study in the laboratory [21, 22]. Lastly, only one sample from a female was retrieved in the present study (case number 4). This sample was found to have lower quantities of the c-Jun and p75NTR mRNA compared to males at a similar denervation time period (Figs. $4 \mathrm{f}$ and $5 \mathrm{f}$ ). This suggests that the repair Schwann cells in this sample are less supportive to neuronal regeneration. This contradicts evidence from rodent models that suggests females exhibit a faster rate of neuronal regeneration compared to males $[83,84]$. It has been shown that this differential may be attributable to a repair Schwann cell phenotype in the distal stump that is sustained for a longer period of time following injury in females compared to males [83, 84]. This warrants studies of additional female nerve samples to compare the time course of repair Schwann cell deterioration to the findings presented here.

\section{Conclusion}

In summary, this study provides new insights into some of the key cellular and molecular features that underpin the regenerative capacity of the human PNS, providing additional explanations for clinical observations and reports. It was found, first, that two major genes associated with repair Schwann cells in rodents, c-Jun and p75NTR, are also up-regulated in acutely injured human nerves, an observation that encourages the view that rodent models are relevant for learning about human nerve injury. Second, as in rodents, the expression of both of these genes declines during long-term denervation. In rodents, diminishing c-Jun and p75NTR levels mark the general deterioration of repair cells during chronic denervation, a process thought to be a major obstacle to effective nerve repair. The down-regulation of c-Jun and p75NTR reported here provides the first molecular evidence that also in humans, repair cells deteriorate during chronic denervation, and provides markers with which this critical process can be monitored.

\section{Supplementary information}

Supplementary information accompanies this paper at https://doi.org/10. 1186/s40478-020-00921-w.

Additional file 1. Methods and materials Additional explanation of statistical analysis implemented, positive controls used for immunohistochemistry staining and further data from uninjured nerve samples.

\section{Abbreviations}

PNI: Peripheral Nerve Injury; PNS: Peripheral Nervous System; CNAP: Compound Nerve Action Potential; FFMT: Free Functioning Muscle Transfer; p75NTR: Neurotrophin Receptor; RT-qPCR: Real Time-quantitative 
Polymerase Chain Reaction; REC: Research Ethics Committee; DAB 3,3': Diaminobenzidine; HRP: Horseradish peroxidase; HIER : Heat-induced epitope retrieval; RT: Reverse transcription; CDNA: Complementary DNA; GOI: Gene of interest; HKG: Housekeeping gene; NTC: Negative Controls; $C_{T}$ : Threshold cycle; $C_{T: e}: C_{T}$ value for endogenous control; $C_{T: C}: C_{T}$ value for calibrator; RQ: Relative quantification; CMAP: Compound Muscle Action Potential

\section{Acknowledgements}

We are very grateful to Dr. Naomi Guppy for performing the immunohistochemistry and Dr. Bill Andrews for advice and guidance on the RT-qPCR assays presented in this paper. In addition, we would like to thank Ms. Neena Kerai for her help in co-ordinating this study. We also acknowledge Dr. Marco Sinisi and Mr. Mike Fox for the inclusion of their patients in this study. This work was funded by the Royal National Orthopaedic Hospital Charitable Trust, England Golf Trust, Engineering and Physical Sciences Research Council (EP/R004463/1) and a UCL Graduate Research Scholarship.

\section{Authors' contributions}

MW performed and analysed RT-qPCR assays, analysed immunohistochemistry data and wrote the manuscript. SL performed statistical analysis on the data presented in this manuscript. TE assisted in the design of the RT-qPCR assays and reviewed the manuscript. $\mathrm{KJ}$ assisted with data interpretation and writing of the manuscript. RM assisted with data interpretation and writing of the manuscript. TQ contributed to study design and writing of the manuscript. JP contributed to study design and writing of manuscript. The authors read and approved the final manuscript.

\section{Funding}

This work was funded by the Royal National Orthopaedic Hospital Charitable Trust, England Golf Trust, Engineering and Physical Sciences Research Council (EP/R004463/1) and a UCL Graduate Research Scholarship.

\section{Availability of data and materials}

The datasets used and/or analysed during the current study are available from the corresponding author on reasonable request.

\section{Ethics approval and consent to participate}

Informed consent was obtained according to the declaration of Helsinki (39). Ethical approval for this project was provided by the UCL Biobank Research Committee (REC 15.15).

\section{Consent for publication}

Informed consent was obtained according to the declaration of Helsinki (39). Ethical approval for this project was provided by the UCL Biobank Research Committee (REC 15.15).

\section{Competing interests}

The authors declare that they have no competing interests.

\section{Author details}

${ }^{1}$ Peripheral Nerve Injury Research Unit, Royal National Orthopaedic Hospital, Stanmore, UK. ${ }^{2}$ Department of Pharmacology, UCL School of Pharmacy, University College London, London WC1N 1AX, UK. ${ }^{3} U C L$ Centre for Nerve Engineering, University College London, London, UK. ${ }^{4}$ Department of Mechanical Engineering, University College London, London, UK. ${ }^{5}$ Department of Biomaterials and Tissue Engineering, Eastman Dental Institute, University College London, London, UK. ${ }^{6}$ Department of Cell and Developmental Biology, University College London, London, UK.

\section{Received: 27 November 2019 Accepted: 26 March 2020}

\section{Published online: 17 April 2020}

\section{References}

1. Brattain K (2012) Analysis of the peripheral nerve repair market in the in the US

2. Noble J, Munro CA, Prasad VS, Midha R (1998) Analysis of upper and lower extremity peripheral nerve injuries in a population of patients with multiple injuries. J Trauma 45:116-122
3. Boerboom A, Dion V, Chariot A, Franzen R (2017) Molecular Mechanisms Involved in Schwann Cell Plasticity. Front Mol Neurosci 10:38. https://doi. org/10.3389/fnmol.2017.00038

4. Jessen KR, Arthur-Farraj P (2019) Repair Schwann cell update: adaptive reprogramming, EMT, and stemness in regenerating nerves. Glia 67:421437. https://doi.org/10.1002/glia.23532

5. Jessen KR, Mirsky R (2019) The success and failure of the Schwann cell response to nerve injury. Front Cell Neurosci 13:33-33. https://doi.org/10. 3389/fncel.2019.00033

6. Jopling C, Boue S, Izpisua Belmonte JC (2011) Dedifferentiation, transdifferentiation and reprogramming: three routes to regeneration. Nat Rev Mol Cell Biol 12:79-89. https://doi.org/10.1038/nrm3043

7. Scheib J, Höke A (2016) Impaired regeneration in aged nerves: clearing out the old to make way for the new. Exp Neurol https://doi.org/10.1016/j. expneurol.2016.07.010

8. Fu SY, Gordon T (1995) Contributing factors to poor functional recovery after delayed nerve repair: prolonged denervation. J Neurosci 15:3886-3895

9. Saito H, Dahlin LB (2008) Expression of ATF3 and axonal outgrowth are impaired after delayed nerve repair. BMC Neurosci 9:88-88

10. Wu P, Chawla A, Spinner RJ, Yu C, Yaszemski MJ, Windebank AJ, Wang H (2014) Key changes in denervated muscles and their impact on regeneration and reinnervation. Neural Regen Res 9:1796-1809. https://doi. org/10.4103/1673-5374.143424

11. Sulaiman OA, Gordon T (2000) Effects of short- and long-term Schwann cell denervation on peripheral nerve regeneration, myelination, and size. Glia 32: 234-246

12. Hoke A (2006) Mechanisms of disease: what factors limit the success of peripheral nerve regeneration in humans? Nat Clin Pract Neurol 2:448-454. https://doi.org/10.1038/ncpneuro0262

13. Li H, Terenghi G, Hall SM (1997) Effects of delayed re-innervation on the expression of c-erbB receptors by chronically denervated rat Schwann cells in vivo. Glia 20:333-347

14. Terenghi G, Calder JS, Birch R, Hall SM (1998) A morphological study of Schwann cells and axonal regeneration in chronically transected human peripheral nerves. J Hand Surg (Edinburgh, Scotland) 23:583-587

15. Isaacs J, Cochran AR (2019) Nerve transfers for peripheral nerve injury in the upper limb. Bone Joint J 101-B:124-131. https://doi.org/10.1302/0301-620X. 101B2.BJJ-2018-0839.R1

16. M F G, M M, S H, Khan WS (2014) Peripheral nerve injury: principles for repair and regeneration. Open Orthop J 8:199-203. https://doi.org/10.2174/ 1874325001408010199

17. Oberlin C, Beal D, Leechavengvongs S, Salon A, Dauge MC, Sarcy JJ (1994) Nerve transfer to biceps muscle using a part of ulnar nerve for C5-C6 avulsion of the brachial plexus: anatomical study and report of four cases. J Hand Surg 19:232-237. https://doi.org/10.1016/0363-5023(94)90011-6

18. Tung TH, Mackinnon SE (2010) Nerve transfers: indications, techniques, and outcomes. J Hand Surg 35:332-341. https://doi.org/10.1016/j.jhsa.2009.12.002

19. He B, Zhu Z, Zhu Q, Zhou X, Zheng C, Li P, Zhu S, Liu X, Zhu J (2014) Factors predicting sensory and motor recovery after the repair of upper limb peripheral nerve injuries. Neural Regen Res 9:661-672. https://doi.org/ 10.4103/1673-5374.130094

20. Mackinnon SE, Novak CB, Myckatyn TM, Tung TH (2005) Results of reinnervation of the biceps and brachialis muscles with a double fascicular transfer for elbow flexion. J Hand Surg 30:978-985. https://doi.org/10.1016/j. jhsa.2005.05.014

21. Hewitt SM, Lewis FA, Cao Y, Conrad RC, Cronin M, Danenberg KD, Goralski TJ, Langmore JP, Raja RG, Williams PM et al (2008) Tissue handling and specimen preparation in surgical pathology: issues concerning the recovery of nucleic acids from formalin-fixed, paraffin-embedded tissue. Arch Pathol Lab Med 132:1929-1935. https://doi.org/10.1043/1543-2165-132.12.1929

22. Wilcox M, Quick TJ, Phillips JB (2019) The effects of surgical antiseptics and time delays on RNA isolated from human and rodent peripheral nerves. Front Cell Neurosci 13:189-189. https://doi.org/10.3389/fncel.2019.00189

23. Herrera-Perez M, Oller-Boix A, Perez-Lorensu PJ, de Bergua-Domingo J, Gonzalez-Casamayor S, Marquez-Marfil F, Diaz-Flores L, Pais-Brito JL (2015) Intraoperative neurophysiological monitoring in peripheral nerve surgery: technical description and experience in a Centre. Rev Esp Cir Ortop Traumatol 59:266-274. https://doi.org/10.1016/j.recot.2014.11.004

24. Slimp JC (2000) Intraoperative monitoring of nerve repairs. Hand Clin 16:25-36

25. Leechavengvongs S, Witoonchart K, Uerpairojkit C, Thuvasethakul P, Ketmalasiri W (1998) Nerve transfer to biceps muscle using a part of the 
ulnar nerve in brachial plexus injury (upper arm type): a report of 32 cases. J Hand Surg 23:711-716. https://doi.org/10.1016/S0363-5023(98)80059-2

26. Leechavengvongs S, Witoonchart K, Uerpairojkit C, Thuvasethakul P, Malungpaishrope K (2006) Combined nerve transfers for C5 and C6 brachial plexus avulsion injury. J Hand Surg 31:183-189. https://doi.org/10.1016/j. jhsa.2005.09.019

27. Ray WZ, Mackinnon SE (2010) Management of nerve gaps: autografts, allografts, nerve transfers, and end-to-side neurorrhaphy. Exp Neurol 223: 77-85. https://doi.org/10.1016/j.expneurol.2009.03.031

28. Arthur-Farraj PJ, Latouche M, Wilton DK, Quintes S, Chabrol E, Banerjee A, Woodhoo A, Jenkins B, Rahman M, Turmaine M et al (2012) C-Jun reprograms Schwann cells of injured nerves to generate a repair cell essential for regeneration. Neuron 75:633-647. https://doi.org/10.1016/j. neuron.2012.06.021

29. Jang S-W, Srinivasan R, Jones EA, Sun G, Keles S, Krueger C, Chang L-W, Nagarajan R, Svaren J (2010) Locus-wide identification of Egr2/Krox20 regulatory targets in myelin genes. J Neurochem 115:1409-1420. https://doi. org/10.1111/j.1471-4159.2010.07045.x

30. Jessen KR, Mirsky R (2008) Negative regulation of myelination: relevance for development, injury, and demyelinating disease. Glia 56:1552-1565. https:// doi.org/10.1002/glia.20761

31. Kamholz J, Awatramani R, Menichella D, Jiang H, Xu W, Shy M (1999) Regulation of myelin-specific gene expression. Relevance to CMT1. Ann N Y Acad Sci 883:91-108

32. Mirsky R, Woodhoo A, Parkinson DB, Arthur-Farraj P, Bhaskaran A, Jessen KR (2008) Novel signals controlling embryonic Schwann cell development, myelination and dedifferentiation. J Peripher Nerv Syst 13:122-135. https:// doi.org/10.1111/j.1529-8027.2008.00168.x

33. Bremer M, Frob F, Kichko T, Reeh P, Tamm ER, Suter U, Wegner M (2011) Sox10 is required for Schwann-cell homeostasis and myelin maintenance in the adult peripheral nerve. Glia 59:1022-1032. https://doi.org/10.1002/glia. 21173

34. Finzsch M, Schreiner S, Kichko T, Reeh P, Tamm ER, Bösl MR, Meijer D, Wegner M (2010) Sox10 is required for Schwann cell identity and progression beyond the immature Schwann cell stage. J Cell Biol 189:701712. https://doi.org/10.1083/jcb.200912142

35. Miettinen M, McCue PA, Sarlomo-Rikala M, Biernat W, Czapiewski P, Kopczynski J, Thompson LD, Lasota J, Wang Z, Fetsch JF (2015) Sox10 - a marker for not only Schwannian and melanocytic neoplasms but also myoepithelial cell tumors of soft tissue. A systematic analysis of 5134 tumors. Am J Surg Pathol 39:826-835. https://doi.org/10.1097/PAS. 0000000000000398

36. Nonaka D, Chiriboga L, Rubin BP (2008) Sox10: a pan-schwannian and melanocytic marker. Am J Surg Pathol 32:1291-1298. https://doi.org/10. 1097/PAS.0b013e3181658c14

37. Britsch S, Goerich DE, Riethmacher D, Peirano Rl, Rossner M, Nave KA, Birchmeier C, Wegner M (2001) The transcription factor Sox10 is a key regulator of peripheral glial development. Genes Dev 15:66-78. https://doi. org/10.1101/gad.186601

38. Liu Z, Jin Y-Q, Chen L, Wang Y, Yang X, Cheng J, Wu W, Qi Z, Shen Z (2015) Specific marker expression and cell state of Schwann cells during culture in vitro. PLoS One 10:e0123278. https://doi.org/10.1371/journal.pone. 0123278

39. World Medical Association Declaration of Helsinki (2013) Ethical principles for medical research involving human subjects. JAMA 310:2191-2194. https://doi.org/10.1001/jama.2013.281053

40. Rueden CT, Schindelin J, Hiner MC, DeZonia BE, Walter AE, Arena ET, Eliceiri KW (2017) ImageJ2: ImageJ for the next generation of scientific image data. BMC Bioinformatics 18:529-529. https://doi.org/10.1186/s12859-017-1934-z

41. Korenkova V, Slyskova J, Novosadova V, Pizzamiglio S, Langerova L, Bjorkman J, Vycital O, Liska V, Levy M, Veskrna K et al (2016) The focus on sample quality: influence of colon tissue collection on reliability of qPCR data. Sci Rep 6:29023

42. Spandidos A, Wang X, Wang H, Dragnev S, Thurber T, Seed B (2008) A comprehensive collection of experimentally validated primers for polymerase chain reaction quantitation of murine transcript abundance. BMC Genomics 9:633-633. https://doi.org/10.1186/1471-2164-9-633

43. Wang X, Seed B (2003) A PCR primer bank for quantitative gene expression analysis. Nucleic Acids Res 31:e154

44. Bustin SA, Benes V, Garson JA, Hellemans J, Huggett J, Kubista M, Mueller R, Nolan T, Pfaffl MW, Shipley GL et al (2009) The MIQE Guidelines: minimum information for Publication of quantitative Real-Time PCR experiments. Clin Chem 55:611 LP-611622. https://doi.org/10.1373/clinchem.2008.112797

45. Rogers-Broadway K-R, Karteris E (2015) Amplification efficiency and thermal stability of qPCR instrumentation: current landscape and future perspectives. Exp Ther Med 10:1261-1264. https://doi.org/10.3892/etm.2015.2712

46. Livak KJ, Schmittgen TD (2001) Analysis of relative gene expression data using real-time quantitative PCR and the 2(-Delta Delta C(T)) method. Methods (San Diego, Calif) 25:402-408. https://doi.org/10.1006/meth.2001. 1262

47. Gambarotta G, Ronchi G, Friard O, Galletta P, Perroteau I, Geuna S (2014) Identification and validation of suitable housekeeping genes for normalizing quantitative real-time PCR assays in injured peripheral nerves. PLoS One 9: e105601. https://doi.org/10.1371/journal.pone.0105601

48. Caboux E, Paciencia M, Durand G, Robinot N, Wozniak MB, Galateau-Salle F, Byrnes G, Hainaut P, Le Calvez-Kelm F (2013) Impact of delay to cryopreservation on RNA integrity and genome-wide expression profiles in resected tumor samples. PLoS One 8:e79826. https://doi.org/10.1371/journal. pone.0079826

49. Jacobs JM, Love S (1985) Qualitative and quantitative morphology of human sural nerve at different ages. Brain 108(Pt 4):897-924

50. Ochoa J, Mair WG (1969) The normal sural nerve in man. II. Changes in the axons and Schwann cells due to ageing. Acta Neuropathol 13:217-239

51. Karamchandani JR, Nielsen TO, van de Rijn M, West RB (2012) Sox10 and $\mathrm{S} 100$ in the diagnosis of soft-tissue neoplasms. Appl Immunohistochem Mol Morphol 20:445-450. https://doi.org/10.1097/PAl.0b013e318244ff4b

52. Campbell WW (2008) Evaluation and management of peripheral nerve injury. Clin Neurophysiol 119:1951-1965. https://doi.org/10.1016/j.clinph. 2008.03.018

53. Smith S, Knight R (2011) In: Birch R (ed) Clinical neurophysiology in peripheral nerve injuries BT - surgical disorders of the peripheral nerves. Springer, London, pp 191-229

54. Kim HA, Pomeroy SL, Whoriskey W, Pawlitzky I, Benowitz LI, Sicinski P, Stiles CD, Roberts TM (2000) A developmentally regulated switch directs regenerative growth of Schwann cells through cyclin D1. Neuron 26:405416

55. Yang DP, Zhang DP, Mak KS, Bonder DE, Pomeroy SL, Kim HA (2008) Schwann cell proliferation during Wallerian degeneration is not necessary for regeneration and remyelination of the peripheral nerves: axondependent removal of newly generated Schwann cells by apoptosis. Mol Cell Neurosci 38:80-88. https://doi.org/10.1016/j.mcn.2008.01.017

56. Bosse F, Kury P, Muller HW (2001) Gene expression profiling and molecular aspects in peripheral nerve regeneration. Restor Neurol Neurosci 19:5-18

57. Jung $Y, \mathrm{Ng} \mathrm{JH}$, Keating CP, Senthil-Kumar P, Zhao J, Randolph MA, Winograd JM, Evans CL (2014) Comprehensive evaluation of peripheral nerve regeneration in the acute healing phase using tissue clearing and optical microscopy in a rodent model. PLoS One 9:e94054. https://doi.org/ 10.1371/journal.pone.0094054

58. Liu P, Peng J, Han G-H, Ding X, Wei S, Gao G, Huang K, Chang F, Wang Y (2019) Role of macrophages in peripheral nerve injury and repair. Neural Regen Res 14:1335-1342. https://doi.org/10.4103/1673-5374.253510

59. Menorca RMG, Fussell TS, Elfar JC (2013) Nerve physiology: mechanisms of injury and recovery. Hand Clin 29:317-330. https://doi.org/10.1016/j.hcl.2013. 04.002

60. Jessen KR, Mirsky R (2016) The repair Schwann cell and its function in regenerating nerves. J Physiol 594:3521-3531. https://doi.org/10.1113/ JP270874

61. Painter MW (2017) Aging Schwann cells: mechanisms, implications, future directions. Curr Opin Neurobiol 47:203-208. https://doi.org/10.1016/j.conb. 2017.10.022

62. Fontana X, Hristova M, Da Costa C, Patodia S, Thei L, Makwana M, SpencerDene B, Latouche M, Mirsky R, Jessen KR et al (2012) C-Jun in Schwann cells promotes axonal regeneration and motoneuron survival via paracrine signaling. J Cell Biol 198:127-141. https://doi.org/10.1083/jcb.201205025

63. Gomez-Sanchez JA, Pilch KS, van der Lans M, Fazal SV, Benito C, Wagstaff LJ, Mirsky R, Jessen KR (2017) After nerve injury, lineage tracing shows that myelin and Remak Schwann cells elongate extensively and branch to form repair Schwann cells, which shorten radically on Remyelination. J Neurosci 37:9086-9099. https://doi.org/10.1523/JNEUROSCI.1453-17.2017

64. Sulaiman W, Gordon T (2013) Neurobiology of peripheral nerve injury, regeneration, and functional recovery: from bench top research to bedside application. Ochsner J 13:100-108 
65. Hoke A, Gordon T, Zochodne DW, Sulaiman OAR (2002) A decline in glial cell-line-derived neurotrophic factor expression is associated with impaired regeneration after long-term Schwann cell denervation. Exp Neurol 173:7785. https://doi.org/10.1006/exnr.2001.7826

66. Jessen KR, Wagstaff LJ, Gomez-Sanchez JA, Mirsky R (2017) Manipulation of repair Schwann cells to correct regeneration failures due to chronic denervation and advancing age. Glia 65:E56-E56

67. Scheib J, Hoke A (2013) Advances in peripheral nerve regeneration. Nat Rev Neurol 9:668-676. https://doi.org/10.1038/nrneurol.2013.227

68. Chao MV (2003) Neurotrophins and their receptors: a convergence point for many signalling pathways. Nat Rev Neurosci 4:299-309. https://doi.org/10. 1038/nrn1078

69. Gonçalves NP, Mohseni S, El Soury M, Ulrichsen M, Richner M, Xiao J, Wood RJ, Andersen OM, Coulson EJ, Raimondo S et al (2019) Peripheral nerve regeneration is independent from Schwann cell p75NTR expression. Front Cell Neurosci 13:235. https://doi.org/10.3389/fncel.2019.00235

70. Reichardt LF (2006) Neurotrophin-regulated signalling pathways. Philos Trans R Soc Lond Ser B Biol Sci 361:1545-1564. https://doi.org/10.1098/rstb. 2006.1894

71. Aydin MA, Mackinnon SE, Gu XM, Kobayashi J, Kuzon WM Jr (2004) Force deficits in skeletal muscle after delayed reinnervation. Plast Reconstr Surg 113:1712-1718

72. Dahlin $L$ (2006) Nerve injury and repair: from molecule to man

73. Noaman HH, Shiha AE, Bahm J (2004) Oberlin's ulnar nerve transfer to the biceps motor nerve in obstetric brachial plexus palsy: indications, and good and bad results. Microsurgery 24:182-187. https://doi.org/10.1002/micr.20037

74. Liu Y, Wang H (2020) Peripheral nerve injury induced changes in the spinal cord and strategies to counteract/enhance the changes to promote nerve regeneration. Neural Regen Res 15:189-198. https://doi.org/10.4103/16735374.265540

75. Chan KM, Gordon T, Zochodne DW, Power HA (2014) Improving peripheral nerve regeneration: from molecular mechanisms to potential therapeutic targets. Exp Neurol 261:826-835. https://doi.org/10.1016/j.expneurol.2014.09.006

76. Tomita K, Kubo T, Matsuda K, Fujiwara T, Yano K, Winograd JM, Tohyama M, Hosokawa K (2007) The neurotrophin receptor p75NTR in Schwann cells is implicated in remyelination and motor recovery after peripheral nerve injury. Glia 55:1199-1208. https://doi.org/10.1002/glia.20533

77. Yi S, Tang X, Yu J, Liu J, Ding F, Gu X (2017) Microarray and qPCR analyses of Wallerian degeneration in rat sciatic nerves. Front Cell Neurosci 11:22-22. https://doi.org/10.3389/fncel.2017.00022

78. Parkinson DB, Bhaskaran A, Arthur-Farraj P, Noon LA, Woodhoo A, Lloyd AC, Feltri ML, Wrabetz L, Behrens A, Mirsky R et al (2008) C-Jun is a negative regulator of myelination. J Cell Biol 181:625-637. https://doi.org/10.1083/jcb. 200803013

79. Parkinson DB, Bhaskaran A, Droggiti A, Dickinson S, D'Antonio M, Mirsky R, Jessen KR (2004) Krox-20 inhibits Jun-NH2-terminal kinase/c-Jun to control Schwann cell proliferation and death. J Cell Biol 164:385-394. https://doi. org/10.1083/jcb.200307132

80. Ciaramitaro P, Mondelli M, Logullo F, Grimaldi S, Battiston B, Sard A, Scarinzi C, Migliaretti G, Faccani G, Cocito D (2010) Traumatic peripheral nerve injuries: epidemiological findings, neuropathic pain and quality of life in 158 patients. J Peripher Nerv Syst 15:120-127. https://doi.org/10.1111/j.15298027.2010.00260.x

81. McAllister RMR, Gilbert SEA, Calder JS, Smith PJ (1996) The epidemiology and management of upper limb peripheral nerve injuries in modern practice. J Hand Surg (Br) 21:4-13. https://doi.org/10.1016/S02667681(96)80004-0

82. Birch R (2011) Surgical disorders of the peripheral nerves. Springer Science \& Business Media, London

83. Kovacic U, Zele T, Osredkar J, Sketelj J, Bajrovic FF (2004) Sex-related differences in the regeneration of sensory axons and recovery of nociception after peripheral nerve crush in the rat. Exp Neurol 189:94-104. https://doi.org/10.1016/j.expneurol.2004.05.015

84. Stenberg L, Dahlin LB (2014) Gender differences in nerve regeneration after sciatic nerve injury and repair in healthy and in type 2 diabetic GotoKakizaki rats. BMC Neurosci 15:107-107. https://doi.org/10.1186/1471-220215-107

\section{Publisher's Note}

Springer Nature remains neutral with regard to jurisdictional claims in published maps and institutional affiliations.

Ready to submit your research? Choose BMC and benefit from:

- fast, convenient online submission

- thorough peer review by experienced researchers in your field

- rapid publication on acceptance

- support for research data, including large and complex data types

- gold Open Access which fosters wider collaboration and increased citations

- maximum visibility for your research: over $100 \mathrm{M}$ website views per year

At BMC, research is always in progress.

Learn more biomedcentral.com/submissions 